\title{
Effects of Social Investment Programme (N-Power) on Standard of Living of Business Education Graduates in Kano State
}

\author{
Saleh Muhammad Aminu, \\ Faculty of Education,Department of Vocational \& Technical Education \\ Ahmadu Bello University, Zaria, Kaduna State, Nigeria
}

Doi:10.19044/esj.2019.v15n22p205 URL:http://dx.doi.org/10.19044/esj.2019.v15n22p205

\begin{abstract}
This paper focuses on the effects of Social Investment Programme (NPower) on standard of living of business education graduates in Kano State, Nigeria. Social Investment aims at granting youths the power to perform their duties and create change. It has to do with teaching them about their ability to control their lives and change society to inculcate a sense of value. N-Power is one of the five Social Investment Programmes of the Federal Government of Nigeria under President Muhammadu Buhari led administration. Two research questions guided the study with one corresponding hypothesis tested at 0.05 level of significance. The descriptive survey research design was adopted in the study. The population was made up of 26 and 30 volunteers from Nassarawa and Fagge LGAs respectively, and 28 supervisors. A structured questionnaire titled N-power Questionnaire (NPQ) was developed by the researcher and was structured into 4 rating scale. Percentages, mean, and standard deviation were used to answer the research questions and one null hypothesis. The findings revealed that N-power SIP had significant effects in improving the standard of living of business education graduates in Kano State. Based on the findings, a major recommendation highlighted was that States government should commit funds to social investment programmes since it helps to improve the standard of living of volunteers.
\end{abstract}

Keywords: SIP, N-Power, Standard of Living, Business Education, Graduates

\section{Introduction}

Social investment involves granting power to perform duties and create change. To empower youth, therefore, means teaching them on how to use their ability to control their lives and change society to inculcate a sense of value. N-Power is one of the five Social Investment Programmes of the Federal Government of Nigeria under President Muhammadu Buhari led 
administration. The established National Social Investments Programmes (NSIP), in 2016, is focused on tackling poverty and hunger across the country.

The suite of programmes under the NSIP focuses on ensuring a more equitable distribution of resources to vulnerable populations, including children, youth, and women. Since 2016, these combined programmes have supported more than four million beneficiaries country-wide through a fair and transparent process supported by the Ministry of Budget and National Planning (MBNP) and other notable MDAs with aligned goals. (statehouse.gov.ng/policy/economy/national-social-investment-programme).

The social investment programme is the largest single dedicated provision for social investment in Nigeria's economic history (Osinbajo, 2016). N-Power is sub-divided into three main categories of N-Teach, NAgro, and N-Health. The N-power programme is designed to assist young Nigerians between the ages of 18 to 35 to acquire and develop lifelong skills for becoming change makers in their communities and players in the domestic and global markets, given a stipend of N30, 000 Monthly.

Thus, volunteer can enrol for any of the three main categories. Standard of living is the level of wealth, comfort, material goods, and necessities available to a certain socioeconomic class or a certain geographic area. The standard of living includes factors such as income, gross domestic product, national economic growth, economic and political stability, political and religious freedom, environmental quality, climate, and safety (Grosseck, Bran, \& Tiru, 2011). The standard of living is closely related to quality of life. Standard of living can be portrayed in terms of opulence or commodities alone, though it is influenced by them, in favor of the idea that one must consider the balance between functioning (the various living conditions that one can or cannot achieve) and capabilities (the ability to achieve various living conditions). For example, to reach the same level of nutrition as another, one needs a larger command over food if one has a higher metabolic rate (or a larger body frame), if one is pregnant (or breastfeeding), if one has a disease that makes absorption more difficult, if one lives in a colder climate, if one has to toil a lot, or if food has other uses, such as for entertainment, ceremonies, or festivals.

\section{Statement of the Problem}

The inalienable right to life confirmed in the Nigerian Constitution is meaningless in a society where large numbers are poor if the government does not invest significantly in getting people out of poverty. Therefore, the social investment programme might serve as a viable tool to reduce unemployment and improve standard of living. However, social investment programme in Nigeria has been a controversial issue. Also, some school of thought have viewed social investment programme as neither effective nor sustainable as a 
result of corruption (Timothy, 2017). The problem of this study, therefore, is to determine whether the $\mathrm{N}$-power programme has significantly improved the standard of living of unemployed business education graduates in Kano State, Nigeria. In addressing this problem, the following research questions were raised:

1. To what extent has the N-power programme improved the Standard of living of unemployed business education graduates in Kano State?

2. What are the challenges encountered by unemployed business education graduates under the N-power programme in Kano State?

\section{Research Hypothesis}

1. N-power programme has no significant effect on the standard of living of unemployed business education graduates in Kano State, Nigeria.

\section{Significance of the Study}

The government will find the result of this study worthwhile because it will provide them with information about the challenges of the programme and possible ways of improvement. Beneficiaries of the programme from other disciplines will also find the result of this study beneficial because it will provide them with information on how to improve their standard of living.

\section{Literature Review}

The concept of empowerment also depends on power that can be expanded. Assi (2011) stated that understanding power as something you can get at an expense cuts most of us off from power.. A zero-sum conception of power means that power will remain in the hands of the powerful unless they give it up. Although this is certainly one way that power can be experienced, it neglects the way power will remain in the hands of the powerful unless they give it up. The United Nations, the World Bank, and various economists have proposed growth-with-equity or basic human needs approaches to living standards. While there are some disagreement over the essential elements, advocates often equate basic needs with minimum amounts of food, clothing, shelter, water, and sanitation that are necessary to prevent ill health and undernourishment. Morris (1979) took up the task of quantifying these concerns in the form of a Physical Quality of Life Index based on the infant mortality rate, the literacy rate, and life expectancy at age one. In a similar vein, the United Nations (UNDP, 1993) created the human development index, which weighs life expectancy, literacy, and income. In addition, subsequent refinements incorporated a broader definition of education, adjustments for gender discrimination, and income distribution. 
Standard of living is the amount of goods and services produced and available to purchase by a person, family, group, or nation. It does not measure non material characteristics, such as relationships, freedom, and satisfaction (Amadeo, 2017). At the individual level, extreme poverty results in malnutrition, retarded growth, and stunting. Higher incomes enable individuals to purchase a better diet, and their weight also increases correspondingly. Nevertheless, once income is sufficient to satisfy caloric requirements, only modest increase are attainable through changes in the diet. Weight may continue to rise with income because individuals purchase more or better housing and medical care (Abu Husein, Al-Sukkar, Salah, \& Jaradat, 2013). As income increases, consumption patterns change. Environmental variables are not too powerless after attaining the capacity for growth.

\section{Methodology}

Survey research design was used to carry out this study. The population of the study consisted of all N-Teach business education and related courses graduates volunteers in post primary schools in two (2) metropolitan local governments of Kano State. These local governments are Nassarawa and Fagge LGAs. The population consists of a total of 26 and 30 volunteers respectively, and also 28 supervisors, totaling 84 respondents' altogether. This is presented in Table 1 below.

Table 1. Population of the study

\begin{tabular}{lllll} 
LGA & Participants & & Percentage \\
& Volunteers & Supervisors & Volunteers & Supervisors \\
\hline Nassarawa & 26 & 12 & 46 & 43 \\
Fagge & 30 & 16 & 54 & 57 \\
\hline Total & $\mathbf{5 6}$ & $\mathbf{2 8}$ & $\mathbf{1 0 0}$ & $\mathbf{1 0 0}$ \\
\hline
\end{tabular}

Source: N-power Local Coordinating office (Fagge and Nassarawa LGAs)

All volunteers were used as sample since the population was not large. Structured questionnaire was used as the principal means by which data for the study was gathered. To obtain respondent authentic responses, the instrument was designed to maintain respondents` confidentiality. Personal on-the-spot administration of the 84 instruments to the respondent was embraced. The respondents to the instrument were all $\mathrm{N}$-Teach volunteers and school based supervisors, whom were considered to be competent in providing responses to the instrument of research. Collection of data lasted for a period of 3 weeks. 


\section{Results and Discussion}

The questionnaires were administered to 84 respondents comprising of supervisors and volunteers, and all were duly filled and returned. The discussion was made based on the responses obtained from the 84 respondents spread across the 28 schools in the two selected local government areas used for the study. Frequency and percentage were used to answer research questions, while simple regression was used to analyze the hypothesis.

Research Question One: To what extent has the N-power programme improved the standard of living of unemployed business education graduates in Kano State?

Table 2. Responses to N-power programme and improved standard of living of business education unemployed graduate

\begin{tabular}{|c|c|c|c|c|c|}
\hline \multirow[t]{2}{*}{ S/no. } & \multirow[t]{2}{*}{ Item } & \multicolumn{4}{|c|}{ No. of } \\
\hline & & Agreed & $\%$ & Disagreed & $\%$ \\
\hline 1. & $\begin{array}{l}\text { More nutritious food is now what volunteers eat } \\
8 \quad(25)\end{array}$ & & 56 & $(75)$ & \\
\hline & $\begin{array}{l}\text { Stipend had enable volunteers to buy better clothes } \\
\text { (40) }\end{array}$ & & 51 & (60) & 33 \\
\hline 3. & $\begin{array}{l}\text { Most volunteers saved } \geq \# 5000 \text { on monthly basis } \\
\text { (49) }\end{array}$ & & 43 & $(51)$ & 41 \\
\hline 4. & $\begin{array}{l}\text { Volunteers stipend is enough for } 30 \text { days } \\
\text { (83) }\end{array}$ & & 14 & (17) & 70 \\
\hline 5. & $\begin{array}{l}\text { The programme should be permanent on this stipend } \\
\text { (80) }\end{array}$ & & 17 & (20) & 67 \\
\hline
\end{tabular}

(Source: Field Study, 2018)

Table 2 presented the analysis of responses of respondents to research question one. Item one, which sought for responses concerning the feeding style of volunteers, was agreed by 56 respondents representing 75 percent, while 28 respondents representing 25 percent disagreed. Item two which sought responses concerning purchase of better clothing by volunteers was agreed by 51 respondents representing 60 percent, while 33 respondents representing 40 percent disagreed. Item three sought responses concerning amount saved on monthly basis by volunteers, where 43 respondents representing 51 percent agreed, while 41 respondents representing 49 percent disagreed. Item four sought responses concerning adequacy of stipends. Most respondents disagreed with 70 respondents representing 83 percent, while 14 respondents representing 17 percent agreed. Finally, item five which sought response concerning continuity of the programme on the current stipend was disagreed by 67 respondents representing 80 percent, while 17 respondents representing 20 percent agreed. 
Table 3. Responses to $N$-power programme and challenges encountered by business education unemployed graduate

\begin{tabular}{|c|c|c|c|c|}
\hline \multirow[t]{2}{*}{ S/no. } & \multicolumn{4}{|c|}{ No. of Responses } \\
\hline & Agreed & $\%$ & Disagreed & $\%$ \\
\hline 1. Most volunteers are punctual to their duties & 43 & $(51)$ & 41 & (49) \\
\hline Volunteers display mastering of subject matters & 56 & (75) & & 28 \\
\hline $\begin{array}{l}\text { 3. Most volunteers cooperate with school } \\
\text { authorities }\end{array}$ & 15 & $(18)$ & 69 & $(82)$ \\
\hline 4. Most volunteers need special training & 17 & (20) & 67 & $(80)$ \\
\hline $\begin{array}{l}\text { 5. Volunteers are enthusiastic in the discharge of } \\
\text { their } \\
\text { duties }\end{array}$ & 70 & (83) & 14 & (17) \\
\hline
\end{tabular}

(Source: Field Study, 2018)

Table 3 presented the analysis of responses of respondents to research question two. Item one, which sought for responses concerning the punctuality of volunteers, was agreed by 43 respondents representing 51 percent, while 41 respondents representing 49 percent disagreed. Item two, which sought responses concerning mastering of the subject matter of volunteers, was agreed by 56 respondents representing 75 percent, while 28 respondents representing 25 percent disagreed. Item three was disagreed by 69 respondents representing 82 percent, while 15 respondents representing 18 percent agreed concerning cooperation of volunteers with school authorities. Item four concerning volunteers need for induction training was agreed by 17 respondents representing 20 percent, while 80 percent, representing 67 respondents, disagreed that the volunteers needed special training for them to be able to perform their primary assignment. Finally, item five was agreed by 70 respondents representing 83 percent, while 14 respondents representing 17 percent disagreed that most respondents display enthusiasm in the discharge of their duties.

\section{Hypotheses Testing}

The null hypothesis was tested using Regression Analysis. The analysis is presented in Table 4 below.

Research Hypotheses One: N-power programme has no significant effect on the standard of living of unemployed business education graduates in Kano State, Nigeria.

Table 4. Regression analysis of N-power programme on the effect of standard of living of unemployed business education graduates in Kano State, Nigeria.

\begin{tabular}{lcccc}
\hline Model & B & SE & T & Sig. \\
\hline Standard of Living & 0.961 & 0.367 & 1.066 & 0.000
\end{tabular}

$\mathrm{R}^{2}=0.97$ Adjusted $\mathrm{R}^{2}=0.969$

(Source: Field study, 2018) 
Table 4 shows the effect of $\mathrm{N}$-power programme on standard of living of unemployed business education graduates. The result indicated that variation in volunteers' standard of living has been accounted for by about 96 percent as indicated by the adjusted $\mathrm{R}$ value (0.969). The prediction of the contribution of the determination of the independent variable coefficient shows that one-unit increase in standard of living of volunteers will increase the standard of living by 0.961 or 96 percent. The $\mathrm{P}$ - value of 0.000 is lower than the alpha at 0.05 level of significance. This is consistent with the opinion of Gasaymeh and Jwaifell (2013). Thus, the null hypothesis which states that N-power programme has no significant effect on standard of living of unemployed business education graduates in Kano State was rejected.

\section{Conclusion}

Based on the findings of this study, it was concluded that social investment programme (N-Power) had tremendously influenced volunteers' standard of living. One of the challenges encountered by the programme is non-punctuality of volunteers in Kano State, Nigeria. Thus, it is important for the federal government to include a proactive monitoring team for efficient and effective delivery of volunteers' mandate.

\section{Recommendations}

The followings recommendations are hereby given based on the findings from the study:

1. State governments should commit funds to social investment programmes as they help in improving the standard of living of volunteers.

2. The federal government should review the programme so as to encourage active volunteers by offering the permanent and pensionable appointment.

3. Management of public schools should form school base monitoring committee that would assist in overseeing the activities of volunteers, so as to ensure proper implementation.

\section{References:}

1. Amadeo, S. (2017). A comprehensive performance evaluation of the Jordanian customs department using the Balanced Scorecard. Peace Journal of Business Administration, 4(4), 463-484.

2. Abu Husein, Al-H., Al-Sukkar, A., Salah, A., \& Jaradat, A. (2013).The impact of social investment to determine student's orientations: Field study on private universities. International Journal of Business, Humanities and Technology, 3(4), 61-68. 
3. Assi, R. (2011), Are women in Jordan empowered? No. TEDxDeadSea; Theme: Education, Creativity \& Entrepreneurship; Kempinski Hotel Ishtar-Dead Sea. Available at:http://www.tedxdeadsea.com/?p=1574.

4. Gasaymeh, A., \& Jwaifell, M. (2013). A Study of Jordanian graduate students' attitudes toward and use of weblog in a blended learning course. Journal of Information Technology and Application in Education, 2(2), 67-79.

5. Grosseck, G., Bran, R., \& Tiru, L. (2011). Dear teacher, what should I write on my wall? A case

6. study on academic uses of Facebook. Procedia Social and Behavioral Sciences, 15, 1425-1430.

7. Leal, J. C. (2017). "Distance and Distortion: Amadeo Souza Cardoso's and Joan Miró's War-years Painting and the Words that Fail Them."Artl@s Bulletin 6,(2).

8. Morris, N. (2009). How Nigerian youth perceive social networks influence. Computer Science and Information Technology, 1(2), 159164

9. Osinbajo, Y. (2016). 'Fed Government N-power built' The Nations News, 20 June 2018 Avaliable at: <http://thenationonlineng.net/fedgovt-to-build-94-ranches-in-10-states/> Accessed on 17 July 2018

10. Page, N. \& Czuba, C. E. (1999). Empowerment: what is it? Journal of Extension 37(5) Retrieved online Standard Of Living https://www.investopedia.com/terms/s/standard-ofliving.asp\#ixzz514A5bXPQ 